[Vicino Oriente XXII (2018), pp. 163-176]

\title{
GAY IN THE SASANIAN PERIOD: SOME PRELIMINARY NOTES ON ITS CIRCULAR URBAN PLAN
}

\author{
Federica Duva - Sapienza University of Rome
}

This paper examines the Sasanian allegedly circular city of Gay, in the region of Isfahan. Material traces of the city have unfortunately been lost so we are forced to rely on Islamic literary sources alone. After an introduction discussing some aspects of the history of Gay, such as its foundation and possible founder, an attempt shall be made to reconstruct its layout according to the information available in medieval sources and through a comparison with the most renowned Sasanian circular city, Ardashīr Xwarrah/Fīrūzābād. Some hypotheses shall be advanced which aim to investigate new interesting features of the plan of Gay, in particular its connection with Sasanian astronomical beliefs.

Keywords: Iran; Gay; Isfahan; Sasanians circular city; literary sources

Although the exact date of their foundation and even location is still shrouded in partial darkness, at least five cities with perfect or almost perfect circular plans seem to be ascribable to the Sasanian domain: Ardashīr Xwarrah/Fīrūzābād, Dārābgird, Veh Ardashīr, Takht-i Sulaymān, and Gay. Nevertheless, there is no specific literature on this topic and they are mentioned only in works about a single city or as a side issue when discussing other subjects, such as the origin of the plan of the 'Abbasid capital, Baghdad. ${ }^{1}$

This paper considers one of those cities, Gay, in the region of Isfahan (fig. 1), material traces of which have unfortunately been lost over time and the only information currently available must be inferred from medieval Islamic authors. The aim here is obviously not to fill this gap, but rather to provide something worth thinking seriously about for future research. Even if the written sources cannot be relied on fully, as they are often imprecise or linked to more fictitious than historical information, through a study of literary texts we shall attempt to make some observations about the foundation of Gay and its layout. These observations, although hypothetical without archaeological evidence, preliminary consider some aspects of the city's urban history that would be very interesting if investigated further.

\section{THE FOUNDATION OF GAY AND THE SASANIAN PERIOD}

The Shahrestānihā $\bar{\imath}$ Erānshahr is the only Sasanian geographical text that has survived. It provides a list of cities of the Sasanian Empire, organized into provinces, and their builders. Spahān (Middle Persian for Isfahan) ${ }^{2}$ is the fifty-fourth province of southern Iran and its capital Gay is said to have been founded by the gizistag (cursed) Alexander, son of Philip. ${ }^{3}$ Like the Shahrestānihā $\bar{\imath} \bar{E}$ rānshahr, most Islamic sources identify Alexander the Great as the founder of Gay. ${ }^{4}$ As a matter of fact, the Macedonian king's role in the

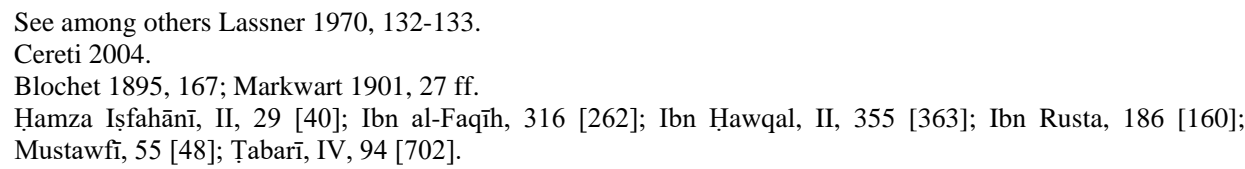


foundation of Gay seems to be a mixture of literary tópoi, a number of traditions centring around him over the centuries that flow into folklore or myth more than into history. Indeed, many Islamic sources interweave Alexander's role in the genesis of Gay with that of legendary Iranian characters, such as Queen Khumānī, Afrāsyāb or Jamshīd.

Another figure who plays a considerable role in the events of Gay is the Sasanian King Fīrūz I (459-484 CE). ${ }^{5}$ He is pre-eminently identified in literary sources as a 're-founder' of the city, a report confirmed by the most authoritative work on Isfahan, the Kitāb Isfahān of Hamza Ișfahānī, ${ }^{6}$ unfortunately lost but partially preserved in works by other Muslim authors, such as Abū Nu 'aym. He reports that Fīrūz I asked the Byzantine Emperor to send him a physician who could identify the best province of Erānshahr in which to build a new imperial residence. Fīrūz I demanded the physician search high and low for a place where the four fundamental elements of the Zoroastrian cult - fire, water, earth and air - coexist so as to guarantee a long and healthy life. ${ }^{7}$ The physician eventually chose the Isfahan province and Fīrūz charged Ādhar Shābūran with the erection of the upper portion of the city wall of Gay, left unfinished since Alexander the Great's time, the step pinnacles and the city gates. The work was accomplished by the architect Farrūkh, son of Bakhtiyār, ${ }^{8}$ one hundred and seventy years before Islam, i.e. around 470-474 CE. ${ }^{9}$ In addition, adjacent to the south-western section of the wall of Gay, King Fīrūz established a village called Ādhār Shābūrān as the aforementioned engineer, where he erected a palace along with a superb paradeisos and a fire temple he bequeathed to the village. ${ }^{10}$ In fact, Fīrūz died shortly after in the battle against the Ephthalites and his son Kawād I (488-531 CE) made a similar request to another Byzantine physician regarding a favourable place of residence: once again Gay was picked from all the Sasanian cities. ${ }^{11}$

Only two authors diverge slightly from this version: Abū'l-Shaykh replaces Fīrūz I with Khusraw I (531-579 CE) as the re-founder of Gay, ${ }^{12}$ while al-Dimashqi instead names Fīrūz I as its factual founder, ${ }^{13}$ proving he was aware of the Sasanian origin of the circular city of Gay, although in a more ancient context, and thus much closer to reality than the other authors.

Moving on to historical and archaeological data on the present-day area of Isfahan, at this point of the knowledge acquired there is no doubt that it was frequented as early as prehistoric times, before and during the Elamite kingdoms (III millennium-640 BC) and later (around 750-550 BC). ${ }^{14}$ The presence of the river Zāyanda and its geographic position

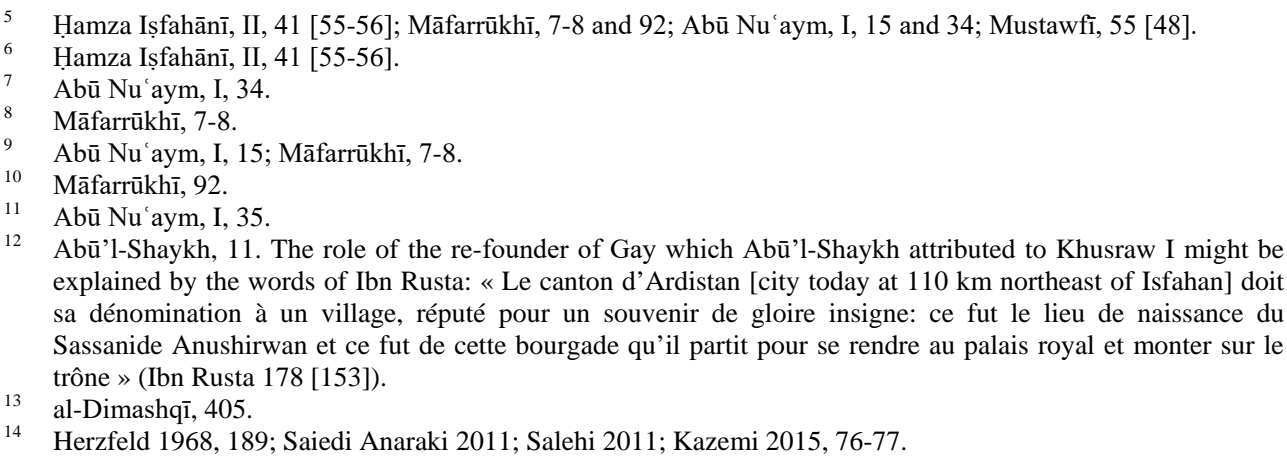

14 Herzfeld 1968, 189; Saiedi Anaraki 2011; Salehi 2011; Kazemi 2015, 76-77. 
in a transitional area between the mountains to the west and the Dasht-i Kawīr to the east increased the fame of the Isfahan region, described in most Islamic sources as a particularly healthy place with an excellent climate and fertile lands, where barley, wheat and millet grew and excellent pastures flourished. Thanks to this agricultural wealth and favourable climate, the oasis of Isfahan has always been identified as a strategic territory for settlements and dominated a very large area, since its latitude enabled communication between the northern and southern regions of the Iranian plateau. Many ancient caravan tracks ran through the Isfahan province dating back to the commercial traffic of prehistoric times, ${ }^{15}$ particularly exploited in the Parthian and Sasanian periods to the point that King Yazdagird I (399-420 CE) established Jewish communities along the north-southern Iranian trade route (in particular at Shūsh and Shūshtar) in order to consolidate and increase contacts between the southern and northern parts of Iran. ${ }^{16}$

Epigraphic evidence indicates that during the Sasanian period two politicaladministrative entities coexisted in the modern area of Isfahan, Gay and Spahān, but only Gay was a proper urban entity, being the principal settlement and administrative centre of the region, ${ }^{17}$ while at that time Spahān had 'provincial status'. In fact, under the Sasanians Gay became the shahristān ${ }^{18}$ of the province, ${ }^{19}$ a sort of provincial capital or big city, the seat of the local representative of royal power. Gay can be found in Shābūr I's inscription (circa 239-270 CE) at the Ka'ba-yi Zardusht in Naqsh-i Rustam in the list of royal officials, in which a shahrab (governor) of Gay is registered. ${ }^{20}$

Three important Sasanian fire temples - Shahr Ardashīr, Zarwān Ardashīr and Mihr Ardashī $^{21}$ - were found near to Gay, respectively in the villages of Māhrbīn, ${ }^{22}$ Dārak $^{23}$ and Ardistān. The Māhrbīn temple is still visible about $10 \mathrm{~km}$ west of Isfahan, and today is simply known as atashgāh.

Archaeological evidence datable to the Sasanian period in the Isfahan area is growing following research carried out in recent decades. The fortress of Shāhdizh can be found in the southern periphery of the modern city, up on the Kuh-i Suffa. It may be part of a wide and complex fortified system spread throughout the Isfahan region, which has recently undergone archaeological excavations that attest the presence of remains with Sasanian architectural features. ${ }^{24}$ Moreover, in the 2000s some excavations were carried out at Tepe Ashraf, near the shore of the Zāyanda river and adjacent to the Sasanian Shahristān bridge,

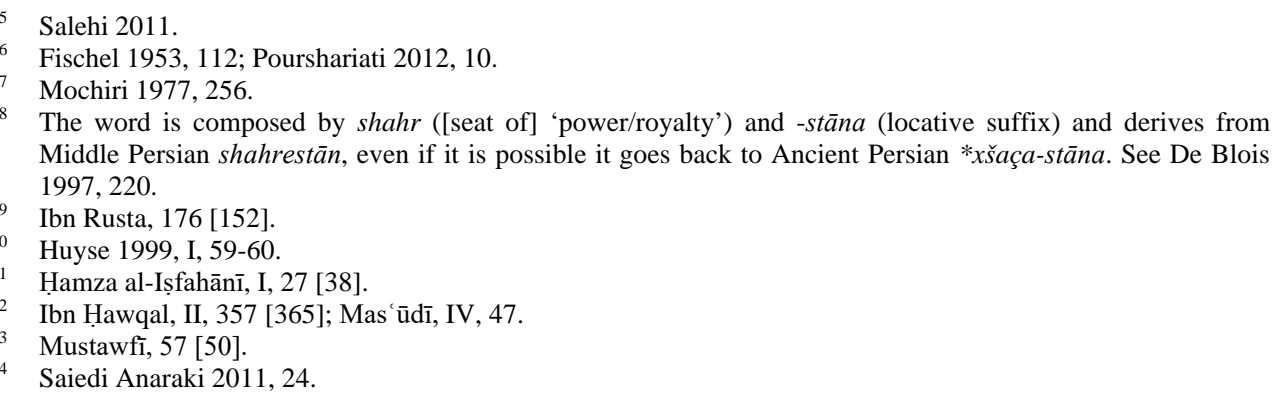


during which Parthian layers were brought to light along with a building with stone-block foundations and solid earth brick walls dated to the Sasanian period. ${ }^{25}$

Although this is not the right place to deal with the identification of the actual founder of Gay, it is still possible to make few observations in this regard.

The emphasis Islamic literary sources place on Fīrūz I's involvement in the foundation of Gay might suggest that he was responsible for the city being built. However, there are three facts that make it implausible that Fīrūz I was its founder: the inscription on the aforementioned Ka'ba-yi Zardusht dated to the $3^{\text {rd }}$ century CE, the presence of a Nestorian Episcopal seat at Gay since at least $430 \mathrm{CE}^{26}$ and the attestation of a profitable mint in Gay since the reign of Bahrām IV (388-399 CE). ${ }^{27}$ Consequently, there are two different possibilities. Firstly, it can be argued that the sovereign actually 're-built' the city, thus accepting what most Islamic sources state, and only restored some parts of the urban fortifications. Alternatively, the patronage of Fīrūz I might be a later supposition. Indeed, it is interesting to observe that literary sources assigning the circular walls to Fīrūz I are all contemporary to or later than 'Adud al-Dawla (949-983 CE), the Buyid sovereign who renamed the Sasanian circular city of Ardashīr Xwarrah Fì $r \bar{u} z \bar{a} b \bar{a} d$. The meaning of the name is still under discussion: the etymology could signify both 'Victory town' ${ }^{28}$ or 'Fīrūz's abode', alluding to the Sasanian king Fīrūz I. In the $10^{\text {th }}$ century was the urban circular model of Fīrūzābād, actually constructed by Ardashīr I (224-241 CE), believed to have been built by Fīrūz? If so, was a similar association also made for Gay? On the basis of some striking urban similarities between Gay and Fīrūzābād, which will be discussed in the next paragraph, it might be hypothesised that they had the same patron, i.e. Ardashīr I. According to Tabarī, Ardashīr I arrived in the region of Isfahan and killed the local king Shādh-sābūr as he proceeded to expand his power beyond Fars, but before his conflict with Artabanus V, the last of the Arsacid dynasts. ${ }^{29}$ Tabarī does not mention a governor being appointed on that occasion, but as soon as the reign of Ardashīr's son, Shāpūr I, there was already a shahrab of Gay.

Nevertheless, although this is an exciting hypothesis, with no other evidence the question of the real founder of Gay remains open.

\section{THE LAYOUT OF GAY}

Unfortunately, there is no archaeological data of the circular city of Gay, which was slowly abandoned over two centuries following the Islamic conquest and replaced by the neighbouring 'Abbasid city of Yahūdiyya (the prodromal Isfahan, founded in $767 \mathrm{CE},{ }^{30} 2$

25 The archaeological data concerning the excavations on Tepe Ashraf, still in progress, have never been published by Jafari-Zand. Information provided here are taken from interviews given by the same archaeologist in several newspapers available online.

26 The Isfahan province became very important for the Christian community as early as the $5^{\text {th }}-6^{\text {th }}$ centuries, since the Nestorian Episcopal seat was in Gay. The diocese was subordinate to that of Elam and in 794-795 we still find in the letters of Patriarch Timothy I (727-823 CE) the Nestorian office of 'bishop of Jayy' جي an Arabisation of the Middle Persian Gay (Markwart 1901, 30).

27 Mochiri 1977, 257; Cereti 2004

28 Barthold 1984, 159

29 Ṭabarī, 5, 12 [818].

30 Duva 2017. 
miles away from Gay), ${ }^{31}$ and subsequently obliterated by building activities over the following centuries. In any case, some distinct construction features or measurements of Gay's urban layout can still be inferred from the descriptions left by some Islamic literary sources.

Ibn Rusta, a geographer who was born and grew up in Isfahan in the $10^{\text {th }}$ century, seems to record the most detailed account of Gay. He describes Isfahan, its districts and Gay, and includes some different measurements for the latter personally calculated by the astronomer Muhammad ibn Ludda Iṣfahānī who stated as follows:

\begin{abstract}
« Je me suis évertue, dit-il, de la connaître et d'en prendre les mesures. Je calculai que sa circonférence était de 1000 perches, ce qui équivaut à 6000 coudées, ou encore à une demi-parasange, puisque la parasange est égale à 12000 coudées. La superficie de la cité est de 2000 arpents de dihqan : en effet, le diamètre est de 320 perches, et si l'on multiplie la moitié du diamètre par la demi-circonférence, on obtient un total de 80.000 perches, ce qui est l'équivalent de 2000 arpents. Le rempart est garni de cent tours et percé de quatre portes, lesquelles sont : le bab Khur ; le bab Isfidj ; le bab Tirah ; et le bab Yahudiyya. J'ai contrôlé personnellement à l'extérieur de la muraille les distances qui séparent les portes les unes des autres. De la porte de Khur à la porte Yahudiya il y a 1100 coudées et dix-huit tours de la porte à la porte de Tirah, 2200 coudées et vingt-trois tours; de la porte de Tirah à la porte d'Isfidj 1300 coudées et vingt-quatre tours ; de la porte d'Isfidj à la porte de Khur, 2400 coudées et trente-cinq tours. Si l'on en croit certains livres perses la ville d'Ispahan avait une longueur de 1750 coudées sur une largeur de 2625, ce qui donne une surface de 1825 arpen de dihqan ; la circonférence était de 7100 coudées, ce qui fait en perches 1183. Mais les mesures que j'ai prises moimême sont plus justes ». ${ }^{32}$
\end{abstract}

Abū'l-Shaykh, Ibn Khurdādhba, Māfarrūkhī and Ibn Ḥawqal also briefly deal with Gay. Abū'l-Shaykh and Ibn Khurdādhba confirm the same number of towers as Muhammad ibn Ludda Ișfahān̄̄'s account, while only Ibn Hawqal records 365 towers in total. ${ }^{33}$ Māfarrūkhī and $\mathrm{Abū} \mathrm{Nu}$ 'aym report a different name for both $b \bar{a} b$ al-Yahüdiyya, i.e. bāb Gushbar, and $b \bar{a} b$ Isfijj, known alternatively as $b \bar{a} b M \bar{a} h$. They further add that one of the gates bore an inscription recording the amount of 600,000 dirham as having been spent on workers' and artisans' wages before the works were even completed. ${ }^{34}$ Nonetheless, despite the alterations, omissions or misinterpretations probably due to a different transmission chain, all these authors seem to rely for the description of Gay on a more ancient common work, most probably the Kitāb Ișfahān of Ḥamza Iṣfahānī.

31 Ibn Hawqal, II, 354 [362]. Two theories on the possible geographical location of Gay, with which the present author does not agree, have been advanced respectively by Golombeck 1974 and Kazemi 2014.

32 Ibn Rusta, $187 \mathrm{ff}$ [160 ff]. In the $10^{\text {th }}$ century the primitive nucleus of Isfahan (the city of Yahūdiyya) was already formed. It lay 2 miles from Gay/Jayy, still visible and inhabited at that time, although by then most of the populace was living in the village of Shahristān, the 'suburb' of the Sasanian round city.

33 Abū'l-Shaykh, 11; Ibn Khurdādhba, 161; Ibn Hawqal, II, 355 [363].

34 Māfarrūkhī, 92-93; Abū Nu'aym, I, 15. 
Hence, the city's perimeter corresponded to 6000 cubits or 1000 perches. First of all, since we shall make some conversions from cubits to metres, a brief digression on the value of the cubit is deemed necessary. In fact, a considerable number of different cubits were in common use in the dār al-Islām throughout the centuries, all based on the Nilometer cubit of the year 861, which on average measures $54.04 \mathrm{~cm}$. Among all these values, only two types of cubit can be taken into account here, proving to be more suitable to our historical and geographical context: the legal cubit (al-dhira $\bar{a}^{\prime}$ al-shar iyya) measuring $49.8 \mathrm{~cm}$, established at the time of caliph al-Ma' mūn (813-833 CE) in Baghdad as some $48.25 \mathrm{~cm}$; the Persian cubit, generally called gaz, which corresponded in the Middle Ages either to the legal cubit of $49.8 \mathrm{~cm}$ or the Isfahan cubit of $79.8 \mathrm{~cm}$.

We shall arbitrarily use the legal cubit to calculate the following measurements of the city of Gay, since it is roughly contemporary to the time of the aforementioned Islamic authors, i.e. the late 'Abbasid and Buyid periods.

Consequently, the perimeter of Gay's circular fortifications can be calculated as approximately $3 \mathrm{~km}(6000 \times 49.8 \mathrm{~cm})$, a distance that matches the 320 perches of the diameter, since we gave one perch a value of around $3.2 \mathrm{~m}^{35}$ for a total of ca. $1024 \mathrm{~m}$. The aforementioned Muslim authors also inform us of how many cubits made up the span between the four gates. For Abū'l-Shaykh the total was 5900 cubits, for Ibn Rusta 7000 cubits, and for Abū Nu'aym 4900 cubits. Although Abū'l-Shaykh's measurement seems closer to the 6000 cubits of the whole perimeter, the total length of the circumference must also include the projection of the $100-104^{36}$ towers, and 100 cubits of difference does not seem enough to factor in this element. Instead, the 7000 cubits as the sum of the spans recorded by Ibn Rusta exceeds the total perimeter. Therefore, only the remaining 1100 cubits (i.e. 6000 - 4900; around $548 \mathrm{~m}$ ) of Abū Nu'aym's account allow comprising the overhang of the bastions in the calculation of the perimeter, assigning circa $5 \mathrm{~m}$ to each tower.

For the sake of completeness, it is noted here that in reporting the measurements of the city of Gay, Abū'l-Shaykh, Ibn Rusta and Abū Nu'aym curiously provided two measurements - length and width - which do not belong to a circular form, which the walls of Gay had. The three authors insert the length and width measurements into the passage in which Muhammad ibn Ludda Ișfahānī describes Gay and assigns them to other mathematicians complaining about their wrongness. Ibn Rusta reports a length of 1500 cubits and a width of 2625 cubits; instead, both Abū'l-Shaykh and Abū Nu 'aym report a length of 1500 cubits and a width of 1752 cubits. These measurements surely cannot match a circle, but rather the major axis and lower axis of an ellipse: the longer one was 1752 cubits, i.e. about $872 \mathrm{~m}$, and the shorter one 1500 cubits, about $747 \mathrm{~m}$. We certainly trust Muhammad ibn Ludda Ișfahānī when he stated that these measurements are wrong, but it is also intriguing to wonder whether the city had an internal wall, slightly ellipsoidal, whose major and minor axes were $872 \mathrm{~m}$ and $747 \mathrm{~m}$, respectively, and whose perimeter can be reckoned as approximately $2.5 \mathrm{~km} .{ }^{37}$ Thus in a completely hypothetical case, the fortifications of the city would have had a perfectly circular shape outside, giving a

Arioli 1979, 65.

100 in Abū'l-Shaykh, 100 in Ibn Rusta, 104 in Abū Nu 'aym.

The following formula was used to calculate the perimeter of the ellipse: $p \approx 2 \pi \sqrt{\frac{a^{2}+b^{2}}{2}}$ 
diameter of 320 qașaba, and a second concentric minor wall - as in Fīrūzābād, Dārābgird, Baghdad. The interval between the two walls (the so-called fașil) would have therefore spanned between ca. $76 \mathrm{~m}$ and $140 \mathrm{~m}$.

Although the circular city has been completely lost, some solar-astronomical considerations in the establishment of Gay can be reconstructed based on literary sources. ${ }^{38}$ We know that the city walls were pierced by four gates. Islamic authors do not specify their precise location along the wall's circumference, but it can still be deduced from a curious account of a distinct feature of Gay's urban layout recorded in the sources. ${ }^{39}$ When the sun reached the 'first degree' of the Tropic of Capricorn dawn was visible through the Khūr Gate and sunset through the Yahüdiyya Gate, while when the sun reached the 'first degree' of the Tropic of Cancer dawn was visible through the Isfij Gate and sunset through the Tirrah Gate. ${ }^{40}$ As a result, the sun's orbit was always at the right distance in both summer and winter and the heat felt varied during the different months, thus benefiting corporal and spiritual wellness.

This phenomenon is due to the inclination of the Earth's rotation axis, which causes the point at which the sun rises not to be absolute as is, instead, the 'conventional position' of the cardinal points. At first glance, it is not clear what the literary sources mean by 'first degree', but it is evident that the four gates were positioned by means of precise mathematical and astronomical calculations so that the rise and fall of the sun could pass through the four entrances depending on the different seasons of the year. ${ }^{41}$ According to the passage above, in general terms it can be said that the Khūr and Isfij Gates were certainly positioned on the semi-circumference facing east, since the dawn was visible from both. Instead, the Yahūddiyya and Țirah Gates were on the semi-circumference facing west. We can also say with some confidence that the two pairs of doors were likely symmetrical to the north-south axis of the walls, but their exact position depends on the latitude on which the city was positioned.

Following a closer examination, it appears that this astronomical peculiarity of the urban layout of Gay strongly calls to mind the following passage taken from the fifth chapter of the Bundahishn: ${ }^{42}$

«Of Mount Alburz it is declared, that around the world and Mount Terak, which is the middle of the world, the revolution of the sun is like a moat around the world; it turns back in a circuit owing to the enclosure (var) of Mount Alburz around Terak. As it is said that it is the Terak of Alburz from behind which my sun and moon and stars return again. For there are a hundred and eighty apertures (rojin) in the east, and a hundred and eighty in the west, through Alburz; and the sun, every day, comes in through an aperture, and goes out

38 Two articles published by Kazemi in 2014 and 2016 deal with the astronomical implications of Sasanian constructions. In the first article the author focuses in particular on the city of Gay and the Sarvistān.

39 Abū Nu'aym, I, 16; Ibn Rusta, 187 [161]; Māfarrūkhī, 92.

40 Ibn Rusta, 179 [154].

41 A first attempt at reconstructing the walls of Gay was proposed by Lisa Golombek as part of a series of studies on the city of Isfahan. Golombek's model shows the Khūr Gate in the northeast, the Yahūdiyya Gate in the northwest, the Țirah Gate in the southwest, and finally the Isfij Gate in the southeast (Golombek 1974, fig. 2).

42 Encyclopaedic collection of Zoroastrian cosmogony and cosmology. 
through an aperture; and the whole connection and motion of the moon and constellations and planets is with it: every day it always illumines (or warms) three regions (karshwar) and a half, as is evident to the eyesight. And twice in every year the day and night are equal, for on the original attack, when it (the sun) went forth from its first degree (khurdak), the day and night were equal, it was the season of spring; when it arrives at the first degree of Kalachang (Cancer) the time of day is greatest, it is the beginning of summer; when it arrives at the sign (khurdak) Tarachuk (Libra) the day and night are equal, it is the beginning of autumn; when it arrives at the sign Vahik (Capricorn) the night is a maximum, it is the beginning of winter; and when it arrives at Varak (Aries) the night and day have again become equal, as when it went forth from Varak. So that when it comes back to Varak, in three hundred and sixty days and the five Gatha days, it goes in and comes out through one and the same aperture; the aperture is not mentioned, for if it had been mentioned the demons would have known the secret, and been able to introduce disaster». ${ }^{43}$

Thus, the points referred to in the sources as 'first degree' of the Tropic of Capricorn and 'first degree' of the Tropic of Cancer represent the winter solstice and the summer solstice, respectively.

Consequently, the exact degree of the sun at dawn and sunset during the winter and summer solstices has been established through a simulation using planetarium software. ${ }^{44}$ The simulation was performed by setting the space and time coordinates: the location was

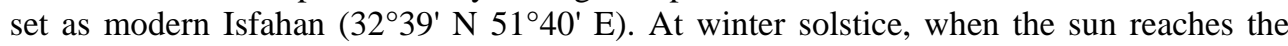
Tropic of Capricorn, the sun rises with an azimuth of $118^{\circ}$ and sets at $242^{\circ}$ and so the dawn was visible at Gay at $28^{\circ}$ south of east and the sunset at $28^{\circ}$ south of west. As for the summer solstice, when the sun reaches the Tropic of Cancer, we find values specular to those just indicated: the sun rises with an azimuth of $62^{\circ}$, i.e. $28^{\circ}$ to the north of east, and sets at $28^{\circ}$ north of west, with an azimuth of $298^{\circ}$. Therefore, the four gates were not at the vertexes of a square inscribed in the circumference of the walls, but rather at the vertexes of an isosceles trapezoid, with the bases positioned in an east-west direction and the tops in a north-south direction. If we imagine the city from above as seen on a map and the circle that defined it as a compass, we can place the four gates as follows: the Khūr Gate towards the southeast $\left(28^{\circ}\right)$ and the Isfij Gate towards the northeast $\left(28^{\circ}\right)$, the Yahūdiyya Gate towards the southwest $\left(28^{\circ}\right)$ and the Tiirah Gate towards the northwest $\left(28^{\circ}\right) .^{45}$ Nevertheless, we have said that the distance between the four gates reported in the literary sources was not perfectly equidistant, and the number of cubits separating the four gates differed from one to another. Considering the measurements given by $\mathrm{Abu} \mathrm{Nu}$ 'aym as the most accurate, as already stated, the distance slightly increased between the Isfij and Khūr Gates (1400 cubits), and between the Isfīj and Tīrah Gates (1300 cubits), in comparison to the 1100 cubits between the other two pairs. Thus, the gates were not placed perfectly on the coincidence of the $28^{\circ}$ corners formed by the two solstices: the Khūr Gate should be

Bundahishn, V.3-7 (West edition)

44 stellarium.org/it/ (last accessed 26/06/2018).

45 The association between Tîr and the summer solstice is reiterated in the Zoroastrian calendar where the month of Sirius, called $T \bar{\imath} r$, is the one that begins with the summer solstice, when the sun is in the sign of Cancer. 
moved some degrees southward to broaden the chord that separated it from the Isfij Gate and to shorten the chord that divided the Yahūdiyya Gate and the Khūr Gate.

Confirmation that the $b \bar{a} b$ al-Yahüdiyya and the $b \bar{a} b$ Kh $\bar{u} r$ were located on the southern section of the circumference comes from Ibn Rusta's account. In fact, he records the opening of a new gate in the city wall after the advent of Islam, ${ }^{46}$ stating that Muhammad ibn Mahmud opened the $b \bar{a} b$ al-jadìd, 'the new gate' - with a single swing unlike the other entrances - blocking the Khūr Gate off. ${ }^{47}$ The choice did not follow mathematical or astronomical calculations, but logistical ones, as the new gate was the most suitable access to the city and the fastest way to reach the Zāyanda Rūd, being the closest to the river. In addition, we know from Ibn Hawqal that the village of Karīna, located just off the Khūr Gate where the Nawrūz celebration was held in his time, was situated along the river. ${ }^{48}$

The information about Gay deduced so far in this paper through the study of historical texts allows a strict comparison between Gay and the other Sasanian 'circular or almost circular' cities. In particular, the city of Ardashīr Xwarrah/Fīrūzābād displays some strict similarities. It is the only perfectly circular Sasanian city with a certain date that still exists, ${ }^{49}$ whose attribution to the reign of the first Sasanian King Ardashīr I is not disputed among scholars.

The fortifications of Fīrūzābād consist of two concentric walls, an internal one and a second external one; a moat about $30 \mathrm{~m}$ wide divides the two city walls and six openings are located along the walls. The innermost city wall has a diameter of $1.8 \mathrm{~km}$, a measurement that coincides with the ancient mil. Considering the width of the moat, the outer wall has a diameter of about $1.95 \mathrm{~km}$. Four of the openings are placed at the four cardinal points and coincide with the intersection between the two axes currently visible and the two walls; in addition, a further opening to the south and another to the north have been documented (fig. 2). Iștakhrī and Ibn Hawqal report that the $b \bar{a} b \mathrm{Mihr}$ was positioned to the east, the $b \bar{a} b$ Ohrmazd to the north, the $b \bar{a} b$ Bahrām to the west and, lastly, the $b \bar{a} b$ Ardashìr to the south. ${ }^{50}$ An internal radial system cut the city area by means of two main orthogonal axes - as a sort of cardo and decumanus. The extreme geometrical precision of the city plan was such that the two axes were perfectly orthogonal crossing in the centre of the circumference where the Tirbāl, a spiral tower-like structure, stood. ${ }^{51}$

In light of the foregoing, it can be argued that Gay and Fīrūzābād shared at least two main urban features: the shape of the external fortification - a perfect circle - and the presence of four principal gates along the walls. Nevertheless, there are two more facts to consider.

First of all, Ibn Rusta and Hamza Ișfahānī inform us of a huge building that stood in the centre of Gay, specifically on the ark: a quhandiz named Sārūq or Sārūya that was still visible at least in the $10^{\text {th }}$ century. ${ }^{52}$ Hence, Gay also had a building erected in the centre of

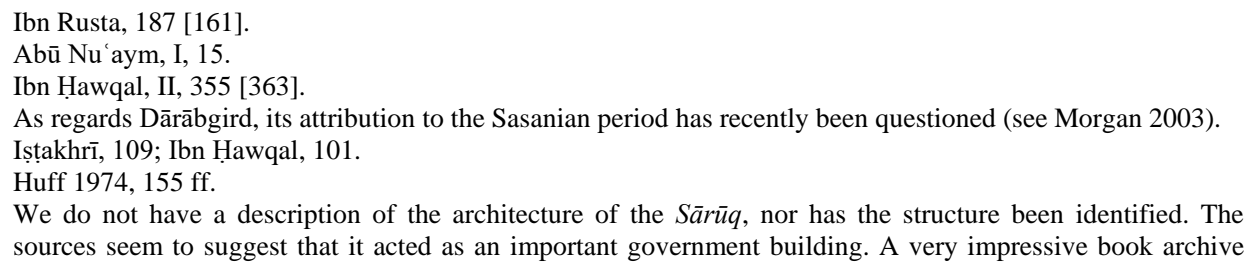


its circumference, overlooking the surrounding area as the Tirbāl correspondingly did in Fīrūzābād. Consequently, it is reasonable to assume that Gay also had two main thoroughfares that departed from the gates and met at the city's centre, shaping the street network and water canalisation, as is still quite evident in Fīrūzābād from aerial or satellite photos.

Another characteristic shared by Gay and Fīrūzābād is the distinct allusion to the Zoroastrian cult sphere and astronomy in the designation of the city gates. With respect to Gay, we have Khūr, from khurshīd, the Persian name for the sun, representing Ohrmazd; Țīrah, which comes from the name of the yazata Tīr, the great Chief of the fixed stars; and Māh, the Persian name for the moon.

The same occurred at Fīrūzābād where the names of three of the four gates had an astronomical link: Mihr, the Sun; Bahrām, Mars; Ohrmazd, Jupiter. ${ }^{53}$ The bāb Mihr is associated, as is the homonymous $b \bar{a} b K h \bar{u} r$ in Gay, with the east and the place where the sun rises. The northernmost gate, called $b \bar{a} b \mathrm{Ohrmazd}$, took its designation from the creator god. The Bundahishn lists four star quadrant-commanders and numerous districtcommanders that exercise jurisdiction over the various parts of the sky; in the arrangement of the leaders, Ohrmazd is associated with Haftōring or Ursa Major, the constellation marking the north. ${ }^{54}$ Furthermore, in Zoroastrian doctrine Ohrmazd is opposed to Ahriman. The principle of evil is associated in Zoroastrian literature with the north, so much so that the Middle Persian term indicating this cardinal point is avoided for fear of evoking its terrible powers. So it may be plausible to suppose that the name Ohrmazd also had apotropaic value: the creator god would have been elected to protect the northern gate from enemy, spiritual and perhaps even material attacks, as possible enemy intervention was in fact expected from the north, as further testified by the presence of the Qal'a-yi Dukhtar. ${ }^{55}$ The western gate on the other hand, the $b \bar{a} b$ Bahrām, may have been linked to the planet Mars, associated with the war god Bahrām. In fact, in the Bundahishn, Bahrām or Mars are connected together with the commander star Wanand/Vega to the west. ${ }^{56}$

The foregoing indisputably reveals a close connection between the urban layout of Fīrūzābād and Gay and Zoroastrian astrological-astronomical beliefs. This is reflected not only in the denomination of the gates, but, above all, in their positioning. As for Gay, it is significant to note here that the names of the aforementioned three gates (Khūr, sun; Māh, moon; Tīrah, the yazata of the fixed stars) are a direct echo of the already quoted passage found in the Bundahishn and also of a formula of the Mihr Niyayishn referring to the good

was placed inside it, full of Middle Persian texts on the most varied disciplines, since there was no building more solid or more suitable for their conservation. There was also a fortress called Sārū $q$ at the centre of Hamadhān's shāhristān (Ibn al-Faqīh, 265 [219]; Mustawfī, 74 [71]; Yāqūt, 295 and 600). Mustawfī describes the city of Hamadhān as having an ancient fortress in adobe, called Shahristān, standing in the city centre and whose erection he attributes to Darius III (330-336 BCE). This ancient citadel is, instead, called Sārūq by Ibn al-Faqīh, who briefly describes it as a fortress with three façades and eight double iron gates. Here too the construction is attributed to Darius III. The meaning of the word $S \bar{a} r \bar{u} q$ is still uncertain.

53 See Huff 1974, $155 \mathrm{ff}$

54 Bundahishn, V.4

55 Rossi 2016.

56 Bundahishn, V.4 
luminaries ${ }^{57}$ associating the sun, moon and fixed stars. Continuing the speculation, it is very interesting to note that the stars, the moon and the sun were all thought to orbit around Mount Tērag, the central point of the Earth, and that there were 'apertures' through which the rays of the sun passed every day. Hence, everything seems to point to the city having been founded as a tangible sign of the universe as the Sasanian believed it to work. The central ark of Gay, emphasised by the presence of the Sarūq, symbolised Mount Tērag, while the city gates represented four of the most important rojin, those coinciding with the summer and winter solstice, key moments of the year.

We believe that further astro-archaeological research on the circular cities, and in particular Gay and Fīrūzābād, should be done. The hypothesis suggested here is intended as a mere first step, but it is in any case a stimulus to continue looking at the influence of royal Sasanian patronage in the erection or foundation of cities and buildings, etc. ${ }^{58}$

\section{REFERENCES}

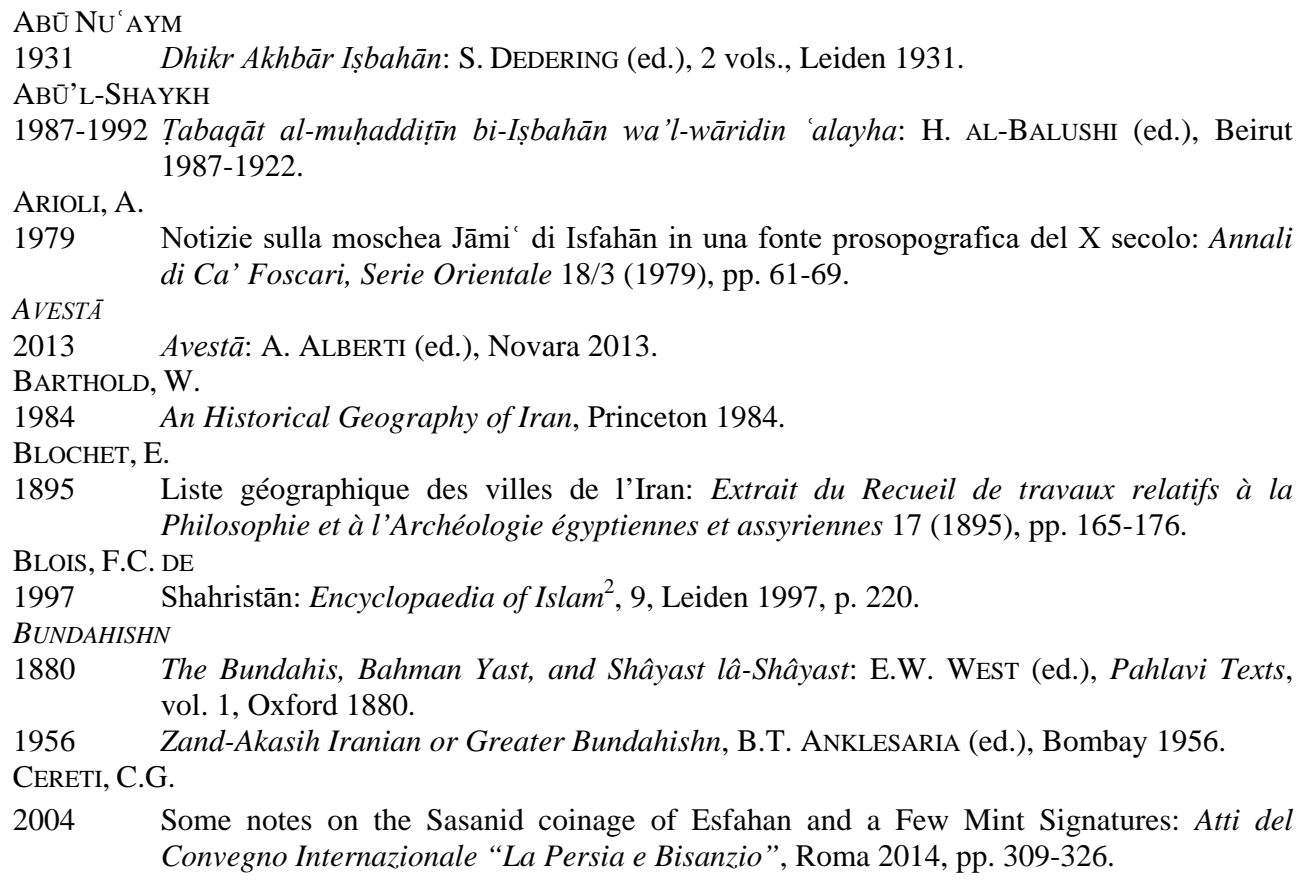

57 «E riveriamo le Stelle, la Luna e il Sole (we reverence the Stars, the Moon, and the Sun)» (Mihr Niyāyishn, 12 in Avestā, ed. Alberti 2013, 229).

58 Another collateral field that should be explored is that of the chart and horoscopes made in order to obtain the best day and time to build or found or act with good auspices. We are very aware of natal charts, but Islamic sources also mention horoscopes used in building practices. For instance, Țabarī states that Kusraw I, when building a dam on the Tigris, consulted his astrologers and magicians for the best auspices (Tabarī, V, 333 [1011-1012]) 
AL-DIMASHQI

1874 Nukhbat al-Dahr fi Aja'ib al-Barr wa'l-Bahr: A.F. MEHren (ed.), Manuel de la DuvA, F. cosmographie du moyen âge, Copenhagen 1874.

2017 New Perspectives on the First Abbasid Masjid-I Jum a of Ișfahān: Vicino Oriente XXI (2017), pp. 97-109.

GOLOMBEK, L.

1974 Urban Patterns in Pre-Safavid Isfahan: Studies on Isfahan. Proceedings of the Isfahan Colloquium, Part I (Iranian Studies 7/1-2), Tehran 1974, pp. 18-44.

HAMZA IȘFAHĀNI

1844 Sinī mulūk al- 'arḍ wa-l-anbīyā: I.M.E. GoTTWALDT (ed.), 2 vols., Leipzig 1844.

HERZFELD, E.

1968 The Persian Empire: studies in geography and ethnography of the ancient Near East, Wiesbaden 1968.

HuFF, D.

1974 An Archaeological Survey in the Area of Firuzabad, Pars in 1972: F. BAGHeRzAdeH (ed.), Proceedings of the 2nd Annual Symposium on Archaeological Research in Iran, Teheran 1973, Tehran 1974, pp. 155-179.

HuYSE, PH.

1999 Die dreisprachige Inschrift Šābuhrs I. an der Ka'ba-i Zardušt (ŠKZ): Corpus IBN AL-FAQĪH Inscriptionum Iranicarum, III/1, vol. 1, London 1999.

1973 Mukhtașar Kitāb al-Buldān, ed. H. Massé, Abregé du Livre des pays, Damascus 1973.

IBN HQWWQAL

1964 Kitāb Șūrat al- 'ard: G. WIET (ed.), Configuration de la terre, 2 vols., Paris 1964

IBN KHURDĀDHBA

1865 Kitāb al-masālik wa al-mamālik: CH. BARBIER De MEYNARD (ed.), Le livre des routes et IBN RUSTA

1955 Kitāb al-Al àk an-Nafǐsa: G. WIET (ed.), Les atours précieux, Le Caire 1955.

IȘṬAKHRĪ

$1870 \quad$ Kitāb al-masālik al-mamālik: M.J. DE GoEJE (ed.), Leiden 1870.

KAZEMI, Y.

2014 An Investigation of Astronomical Features and Calendric Function in Jayy City and the Palace of Sarvestan: Honar-Ha-Ye-Ziba-Memari-Va-Shahrsazi 19/4 (2014), pp. 91-102.

2015 Cultural and Historical Landscape of Ātašgāh-i Isfahān: Buletin Teknologi Tanaman 12/1, Supplement 2, pp. 355-360.

2016 Solar Considerations in Planning of Three Circular Cities in Ancient Persia: Archäologische Mitteilungen aus Iran und Turan 46, pp. 321-330, Berlin 2016.

LASSNER, J.

1970 The Topography of Baghdad in the Early Middle Ages, Detroit 1970.

MĀFARRŪKHĪ

1933 Kitāb maḥāsin Ișfahān: H. ȚiHRĀNī (ed.), Tehran 1933.

MARKWART, J.

1901 Ërānshahr, Berlin 1901.

MAS 'ŪDİ

1861-1877 Murūj adh-dhahab wa ma'ādin al-jawhar, Maçoudi. Les Prairies d'Or. Texte et traduction: Ch. Barbier de Meynard - A. Pavet de Courteille (eds.), 9 vols., Paris 1861-1877. 
MOCHIRI, M.

1977 Etudes de numismatique iranienne sous les Sassanides et Arabe-Sassanides, 2 vols., MORGAN, P.H. Tehran 1977.

2003 Some Remarks on a Preliminary Survey in Eastern Fars: Iran 41 (2003), pp. 323-338.

MUSTAWFī

1919 Nuzhat al-Qulūb,: G. Le StRANGe (ed.), The Geographical Part of the Nuzhat al-Qulūb, London 1919.

POURSHARIATI, P.

2012 New Vistas on the History of the Iranian Jewry in Late Antiquity, part I. Pattern of Jewish Settlements in Iran: H. SARShAR (ed.), The Jews of Iran: The History, Religion and Culture of a Community in the Islamic World, London 2012, pp. 1-32.

Rossi, D.

2016 La città storica di Ardashir-Xwarrah presso Firuzabad (Fars, Iran). Fonti e territorio, MA Thesis, Alma Mater Studiorum University of Bologna (unpublished), 2016.

SAIEDI ANARAKI, F.

2011 Old Isfahan: F. SAIEDI ANARAKI - B. GENIto (eds.), From the Excavation to the Archive: ADAMJI. A Joint Iranian/Italian Project, Tehran 2011, pp. 23-32.

SALEHI, A.KH.

2011 Archaeology, Settlements and Territory in the area of Chenarud, beside the Zayandeh River: F. SAIEDI ANARAKi - B. Genito (eds.), From the Excavation to the Archive: ADAMJI. A Joint Iranian/Italian Project, Tehran 2011, pp. 123-130.

ȚABARĪ

1989-2007 Tārīkh al-Rusul wa al-Mulūk: E. YAR-SHATER (ed.), The History of al-Tabarī, 40 vols., New York 1989-2007.

YĀQūT

1861 Kitāb mu'jam al-buldān, Dictionnaire géographique, historique et littéraire de la Perse et des contrées adjacentes: extrait du Mo'djem el-Bouldan de Yaqout et complété à l'aide de documents arabes et persans pour la plupart inédits: CH. BARBIER DE MEYNARD (ed.), Paris 1861. 


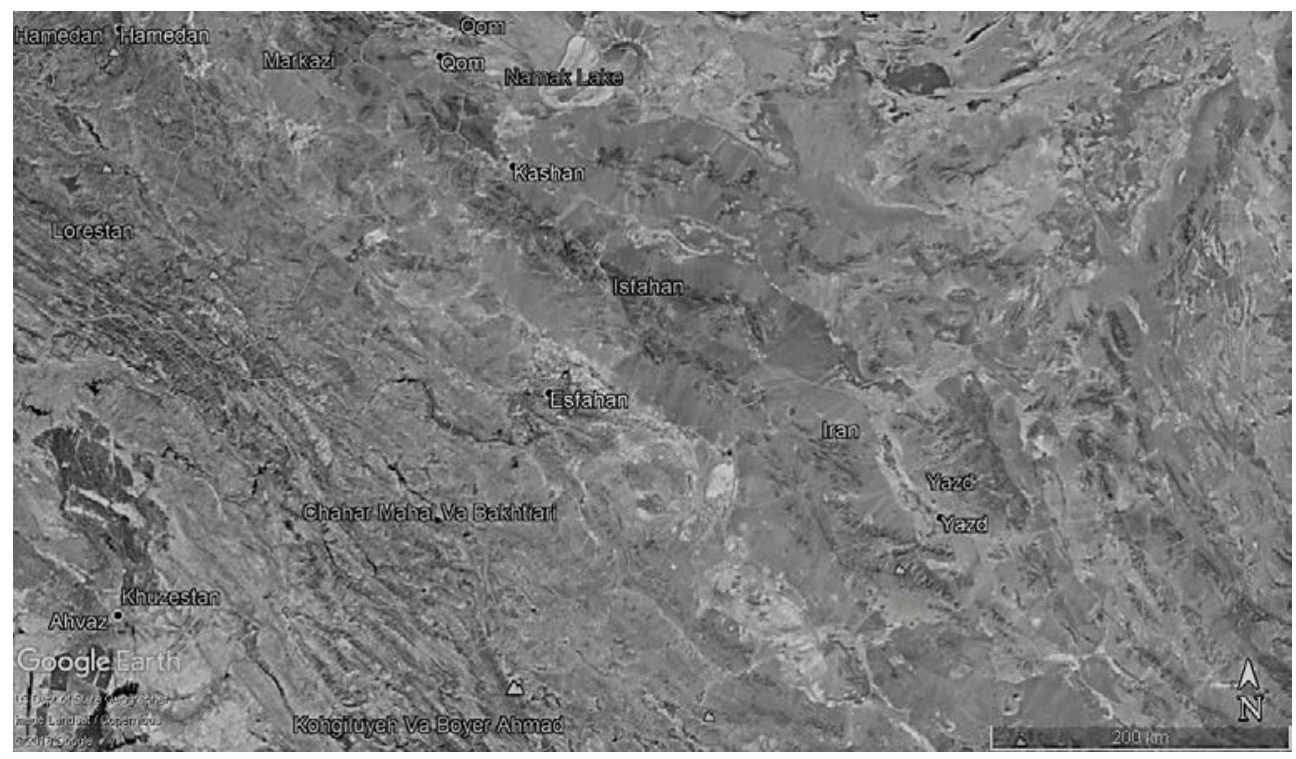

Fig. 1 - The modern region of Isfahan (Google Earth (C)).

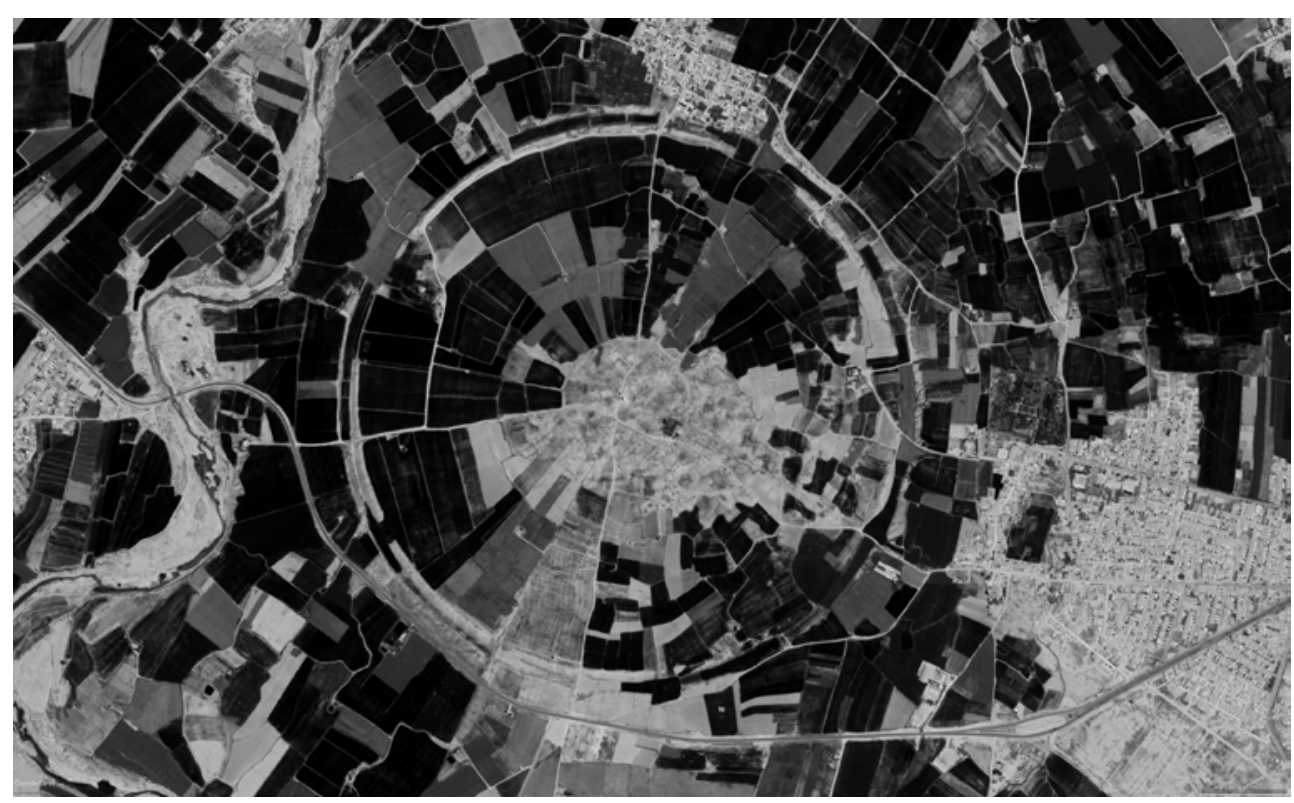

Fig. 2 - The area of Fīrūzābād (Google Earth (C)). 